\title{
GAYA KEPEMIMPINAN, LINGKUNGAN KERJA, KOMPENSASI, MOTIVASI DAN KINERJA PEGAWAI PADA MADRASAH ALIYAH YAYASAN ISLAM RAJAMANDALA
}

\author{
Ani Puspita ${ }^{1}$, Dety Mulyanti ${ }^{2}$, Farida Yuliaty ${ }^{3}$ \\ 1, 2,3 Universitas Sangga Buana, Bandung \\ ${ }^{1}$ korespondensi : push_vitaeni@yahoo.co.id
}

\begin{abstract}
Leadership style, work environment, and compensation are things that need tobe considered in an institution ororganization as well as in a schoolor madrasah because these candirectly or indirectly affect motivation and can have an impact on employee performance. This study aims to determine the leadership style, work environment, compensation, motivation and employe eperformance. And to determine the effect of leadership style, work environment, and compensation on motivation, as well as it's implications for employee performanc eat Madrasah Aliyah Yayasan Islam Rajamandala both partially and simultaneously. the method used isd escriptive verificative. Data collection was carried out by distributing questionnaires to employees in Madrasah Aliyah yayasan Islam Rajamandala, data processing techniques were carried out by path analysis, correlation test, determination coefficient test and hypothesis test. The results showed that the responses regarding the leadership style were in the good category and showed that the leadership at Madrasah Aliyah was more likely tobe participatory, the work environment is in the quite good category, the compensation is in the quite good category too, employees motivation have already been in a good value, and as well as an employees performance. Then leadership style, work environment, and compensation have a positive and significant effect on motivation and performance simultaneously, and motivation has a significant influence on the performance of employees at Madrasah Aliyah Yayasan Islam Rajamandala.
\end{abstract}

Keyword: leadership style, work environment, compensation, motivation, employee performance.

\begin{abstract}
ABSTRAK
Gaya kepemimpinan, lingkungan kerja dan kompensasi merupakan hal yang perlu diperhatikan dalam sebuah institusi atau organisasi, begitupun di sebuah sekolah atau mandrasah karena hal tersebut dapat secara langsung ataupun tidak langsung mempengaruhi motivasi dan dapat berdampak pada kinerja pegawai. Penelitian ini bertujuan untuk mengetahui gaya kepemimpinan, lingkungan kerja, kompensasi, motivasi dan kinerja pegawai, dan untuk mengetahui pengaruh gaya kepemimpinan, lingkungan kerja, dan kompensasi terhadap motivasi serta implikasinya pada kinerja pegawai di Madrasah Aliyah Yayasan Islam Rajamandala baik secara parsial dan secara simultan. Metode yang digunakan adalah deskriptif verifikatif. Pengumpulan data dilakukan dengan menyebarkan kuesioner pada para pegawai dilingkungan Madrasah Aliyah Yayasan Islam Rajamandala. Teknik pengolahan data dilakukan dengan analisis jalur, uji korelasi, uji koefisien determinasi dan uji hipotesis. Hasil penelitian menujukan bahwa tanggapan mengenai gaya kepemimpinan telah berada pada kategori baik dan menunjukan bahwa pimpinan pada madrasah Aliyah lebih cenderung kearah partisipatif, lingkungan kerja berada pada kategori cukup baik, kompensasi juga ada pada kategori cukup baik, motivasi yang dimiliki pegawai berada pada nilai yang baik dan kinerjapun berada pada kategori baik. Kemudian gaya kepemimpinan, lingkungan kerja dan kompensasi berpengaruh positif dan signifikan terhadap motivasi dan terhadap kinerja secara simultan, dan Motivasi memiliki pengaruh yang signifikan terhadap kinerja pegawai pada Madrasah Aliyah yayasan Islam Rajamandala.
\end{abstract}

Kata Kunci: Gaya Kepemimpinan, Lingkungan Kerja, Kompensasi, Motivasi, Kinerja Pegawai.

\section{PENDAHULUAN}

Kinerja pegawai merupakan salah satu faktor penting yang perlu diperhatikan oleh perusahaan, dikarenakan kinerja pegawai adalah sebagai fungsi dari interaksi antara kemampuan dan motivasi. Dalam studi manajemen kinerja pekerja atau pegawai ada hal yang memerlukan pertimbangan yang penting sebab kinerja individual seorang pegawai dalam organisasi merupakan bagian dari kinerja organisasi, dan dapat menentukan kinerja dari organisasi tersebut. Berhasil tidaknya kinerja pegawai yang telah dicapai 
organisasi tersebut akan dipengaruhi oleh tingkat kinerja dari pegawai secara individu maupun kelompok [1]. Salah satu faktor yang dapat meningkatkan kinerja pegawai adalah motivasi, dimana dengan dorongan yang kuat maka seseorang dapat mencapai suatu target yang telah ditetapkan, seperti yang diungkapkan oleh [2] motivasi adalah segala sesuatu yang mendorong atau menggerakkan seseorang untuk bertindak melakukan sesuatu dengan tujuan tertentu, motivasi bisa datang dari dalam diri sendiri ataupun dari orang lain. Dengan adanya motivasi maka seseorang dapat mengerjakan sesuatu dengan antusias, maka dapat dikatakan bahwa semakin baik motivasi yang dimiliki, semakin baik pula kinerja yang dihasilkan [3]. Selanjutnya usaha untuk meningkatkan motivasi dan kinerja pada pegawai, diantaranya adalah dengan memperhatikan kompensasi. Kompensasi merupakan salah satu faktor yang mempengaruhi motivasi dan implikasinya pada kinerja pegawai [4]. Kompensasi yang didapatkan oleh pegawai sebagai bentuk imbalan atas kontribusinya terhadap perusahaan merupakan salah satu sumber motivasi yang sangat kuat, ini dikemukakan oleh penelitian yang dilakukan [5], selain itu dengan Lingkungan kerja baik fisik dan non fisik memiliki hubungan erat dengan motivasi, lingkungan kerja yang baik memberikan pengaruh baik terhadap terhadap motivasi pegawai, hal tersebut telah sesuai dengan penelitian yang dilakukan oleh [3]. Kepemimpinan juga memiliki kontribusi yang cukup besar terhadap motivasi pegawai, dimana semakin baik gaya kepemimpinan seorang pemimpin maka semakin tinggi tingkat motivasi kerja pegawai dan sebaliknya, pada setiap satuan pendidikan pada umumnya gaya kepemimpinan dari seorang kepala madrasah, akan memiliki hubungan yang sangat erat [6]. Pada madrasah Aliyah terdapat beberapa hambatan pada proses manajemennya terutama dapat dilihat dari kinerja pegawai yang menurun disebabkan oleh motivasi yang kurang kuat dari pegawai tersebut, dimana motivasi itu terdorong oleh faktor faktor yang memicu khususnya faktor kepemimpinan, lingkungan kerja, dan kompensasi.

\section{TINJAUAN PUSTAKA}

Hubungan Gaya Kepemimpinan, Lingkungan Kerja, Kompensasi, Motivasi dan Kinerja Pegawai.

Gaya kepemimpinan, lingkungan kerja, dan kompensasi merupakan sebagian dari komponen-komponen yang mempengaruhi motivasi dan tentunya akan berdampak pada kinerja pegawai, kesemua hal ini saling berhubungan satu sama lain yang apabila gaya kepemimpinan, lingkungan kerja dan kompensasi sudah baik maka akan baik pula motivasi, jika motivasi sudah baik maka akan berdampak pada meningkatkanya kualitas kinerja pegawai [7].

$\mathrm{HI}=$ Ada Pengaruh positif antara Gaya Kepemimpinan, Lingkungan Kerja, Kompensasi, Motivasi, dan Kinerja Pegawai di Madrasah Aliyah 


\section{Hubungan Gaya Kepemimpinan dengan}

\section{Motivasi}

Sebagaimana asumsi yang selalu masyarakat percayai bahwa semakin baik gaya kepemimpinan seorang pemimpin maka semakin tinggi tingkat motivasi kerja pegawai dan sebaliknya, pada setiap satuan pendidikan pada umumnya gaya kepemimpinan dari seorang kepala madrasah, akan memiliki hubungan yang sangat erat sesuai dengan penelitian yang dilakukan oleh [6].

H2 = Ada Pengaruh Positif antara Gaya Kepemimpinan Terhadap Motivasidi Madrasah Aliyah

\section{Hubungan Lingkungan Kerja dengan}

Motivasi

Lingkungan kerja baik fisik dan non fisik memiliki hubungan erat dengan motivasi, lingkungan kerja yang baik memberikan pengaruh baik terhadap terhadap motivasi pegawai, dan berdasarkan penelitian yang dilakukan oleh [3].

$\mathrm{H} 3$ = Ada Pengaruh Positif Antara Lingkungan Kerja Terhadap Motivasidi Madrasah Aliyah.

\section{Hubungan Kompensasi denganMotivasi}

Kompensasi yang didapatkan oleh pegawai sebagai bentuk imbalan atas kontribusinya terhadap perusahaan merupakan salah satu sumber motivasi yang sangat kuat, sesuai dengan penelitian yang dikemukakan oleh [5].

$\mathrm{H} 4=$ Ada Pengaruh Positif Antara Kompensasi Terhadap Motivasi di Madrasah Aliyah.
Hubungan Gaya Kepemimpinan dengan Kinerja

Gaya kepemimpinan merupakan sebuah komponen yang dapat mempengaruhi kinerja pegawai, Menurut [8], gaya kepemimpinan berpengaruh positif dan tidak signifikan terhadap variabel kinerja karyawan, ini berarti bila seorang pimpinan memiliki gaya kepemimpinan yang baik maka hal tersebut dapat memberikan pengaruh baik terhadap kinerja pegawainya.

H5 = Ada Pengaruh Positif Antara Kepemimpinan Terhadap Kinerjadi Madrasah Aliyah.

Hubungan Lingkungan Kerja dengan Kinerja

Lingkungan kerja adalah tempat dimana semua pegawai bekerja, lingkungan kerja yang nyaman dengan fasilitas kerja yang optimal akan memberikan pengaruh yang baik terhadap kinerja pegawai, menurut penelitian dari [8].

H6 = Ada Pengaruh Positif Antara lingkungan kerja Terhadap Kinerjadi Madrasah Aliyah.

\section{Hubungan Kompensasi dengan Kinerja}

Kompensasi sangat signifikan mempengaruhi kinerja pegawai, kompensasi mempunyai pengaruh yang positif terhadap kinerja artinya semakin baik kompensasi yang dirasakan pegawai maka kinerja mereka juga semakin baik, [7]

$\mathrm{H7}=$ Ada Pengaruh Positif Antara Kompensasi Terhadap kinerjadi Madrasah Aliyah. 


\section{Hubungan Motivasi dengan Kinerja}

Pegawai yang memiliki motivasi baik dalam bekerja akan senantiasa memberikan hasil kerja yang baik, sesuai dengan tuntutan perusahaan, maka dapat disimpulkan bahwa motivasi memberikan pengaruh terhdap kinerja [9].Selain itu semakin baik motivasi yang dimiliki, semakin baik pula kinerja yang dihasilkan [10].

H8 = Ada pengaruh Positif antara Motivasi

Terhadap Kinerja Di Madrasah Aliyah.

\section{METODE PENELITIAN}

Metode yang digunakan dalam penelitian ini adalah deskriptif verifikatif, dimana dalam pengambilan sampel menggunakan non probability sampling atau sampel jenuh yaitu semua populasi dijadikan sebagai sampel yang berjumlah 30 orang. Data karakteristik responden disajikan pada tabel 1.1 sebagai berikut :

Tabel 1 : Data Responden

\begin{tabular}{|l|l|r|r|}
\hline Karakteristik & Kategori & Frekuensi & Persentase \\
\hline \multirow{5}{*}{ Jenis Kelamin } & Pria & 16 & 53.3 \\
\cline { 2 - 4 } & Wanita & 14 & 46.7 \\
\hline \multirow{5}{*}{ Usia } & $21-30$ Tahun & 8 & 26.7 \\
\cline { 2 - 4 } & $31-40$ Tahun & 8 & 26.7 \\
\cline { 2 - 4 } & $41-50$ Tahun & 11 & 36.7 \\
\hline \multirow{5}{*}{ Pendidikan } & $>50$ Tahun & 3 & 10 \\
\hline \multirow{5}{*}{ Masa Kerja } & SMA & 5 & 16.7 \\
\cline { 2 - 4 } & S1 & 25 & 83.3 \\
\cline { 2 - 4 } & S2 & 0 & 0 \\
\cline { 2 - 4 } & S3 & 0 & 0 \\
\hline & $<1$ tahun & 2 & 6.7 \\
\cline { 2 - 4 } & $1-5$ tahun & 9 & 30 \\
\cline { 2 - 4 } & $5-10$ tahun & 4 & 13.3 \\
\cline { 2 - 4 } & $10-15$ tahun & 12 & 40 \\
\cline { 2 - 4 } & $>15$ tahun & & 10 \\
\hline
\end{tabular}

Sumber : Data yang diolah

Alat analisi yang digunakan adalah path analysis atau analisis jalur dengan struktur model sebagai berikut : 


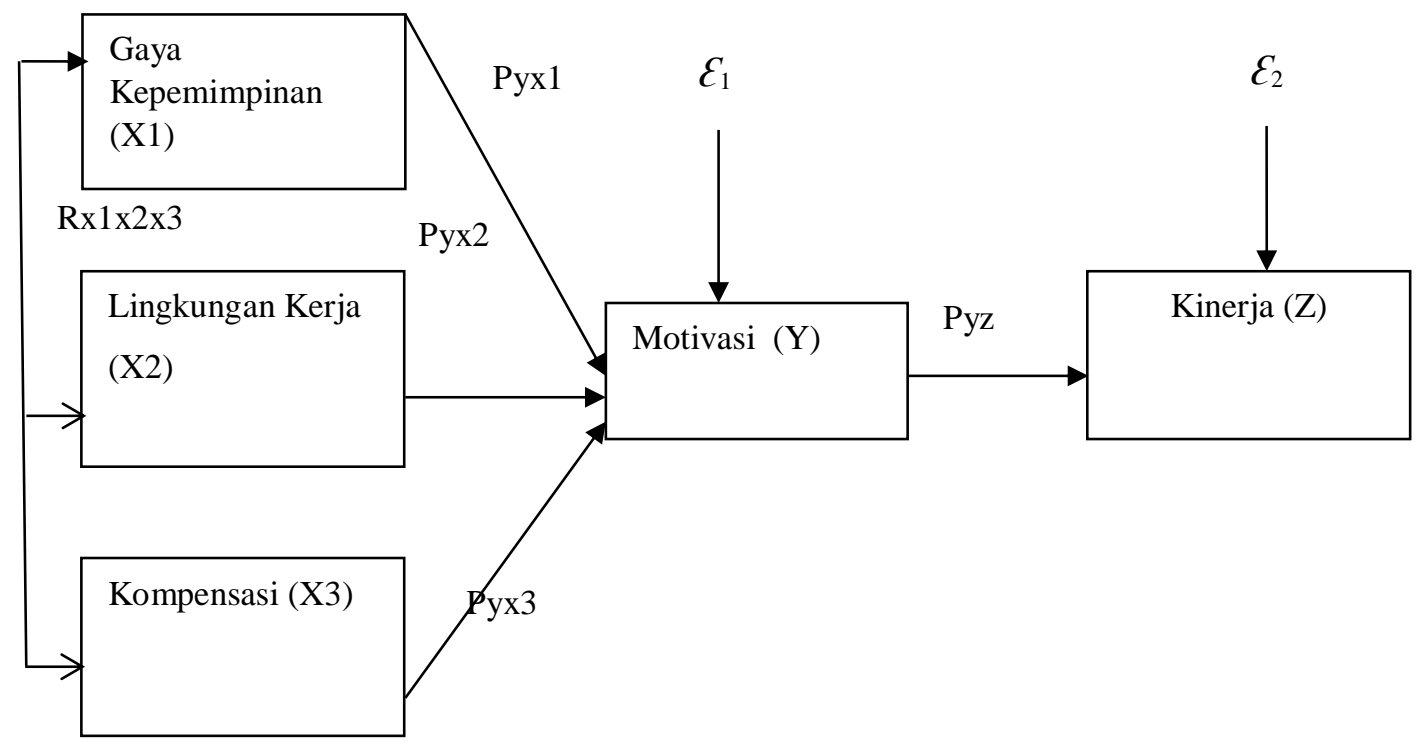

Gambar 1 : Diagram Jalur X1, X2, X3, dan Y terhadap Z

Struktur model tersebut terbagi menjadi 3 struktur yaitu :

1. Substruktur $1: \mathrm{y}=\rho y x 1 X 1+$ $\rho y \times 2 X 2+p y \times 3 \times 3+\varepsilon 1(1)$

2. Substruktur $2: \mathrm{Z}=\rho z y Y+\varepsilon 2$ (2)

3. Substruktur $3: Z=\rho z x_{1} \cdot X_{1}+\rho z x_{2} \cdot X_{2}$ $+p z y(3)$

\section{HASIL DAN PEMBAHASAN}

\section{Uji Validitas, Uji Reliabilitas, dan Uji}

\section{Normalitas}

Tingkat signifikansi pada penelitian ini yaitu $5 \%$. Hasil dari uji validitas pada penelitian ini dinyatakan valid dikarenakan semua $r$ hitung berada diatas $\mathrm{r}$ tabel, untuk uji reliabilitas dinyatakan reliabel dikarenakan semua nilai hitung cronbach alpha berada diatas nilai hitung. Pada uji normalitas dinyatakan berdistribusi secara normal karena berada diatas 0.05 .

\section{Respon Responden}

Gaya kepemimpinan secara rata rata berada pada kategori baik dimana indikator terendah berada pada wewenang mutlak dan wewenang delegasi sedangkan pada skor tertinggi ditunjukan pada indikator partisipasi pegawai dan pimpinan, hal tersebut menunjukan bahwa pimpinan madrasah Aliyah cenderung lebih melibatkan para pegawai didalam pengambilan keputusan maupun kegiatan yang terjadi pada madrasah. Lingkungan kerja berada pada kategori cukup baik dimana indikator terendah berada pada getaran suara dan sirkulasi udara, sedangkan indikator tertinggi berada pada penerangan. Variabel kompensasi berada pada kategori cukup baik dimana indikator terendah berada pada tunjangan jabatan dan gaji \& insentif, sedangkan skor tertinggi berada pada indikator fasilitas kesehatan. Hal tersebut disebabkan karena pimpinan madrasah Aliyah 
lebih mengutamakan kedekatan antar pegawai dibandingkan hasil kinerja dari pegawai itu sendiri. Motivasi berada pada kategori baik dimana indikator terendah berada pada dorongan kerja dan keinginan untuk menjadi lebih baik, sedangkan skor tertinggi ditunjukan pada indikator kerelaan untuk bekerja lebih optimal serta keterampilan. Hal tersebut dikarenakan pegawai madrasah Aliyah merasa kompensasi yang didapatkan belum sesuai dengan beban kerja yang diberikan. Kinerja pegawai berada pada kategori baik dimana skor terendah berada pada indikator kedisiplinan dan target kerja, sedangkan indikator tertinggi yaitu kemandirian. Hal ini menunjukan bahwa tidak semua pegawai madrasah Aliyah telah memiliki kedisiplinan yang baik seperti mengerjakan pekerjaan yang telah diberikan, datang tepat waktu dan pencapaian target kerja yang belum sepenuhnya tercapai.

\begin{abstract}
Analisis Jalur
Anaisi jalur digunakan untuk mengetahui dampak kepemimpinan, lingkungan kerja, dan kompensansi terhadap motivasi dan implikasinya terhadap kinerja.
\end{abstract}

\section{Substruktur 1}

Besarnya pengaruh variabel eksogen terhadap variabel intervening dapat diketahui dari nilai koefisien jalur dari tiap variabel eksogen terhadap variabel intervening. Tabel 1.2 dijelaskan nilai koefisien jalur gaya kepemimpinan, lingkungan kerja dan kompensasi terhadap motivasi.

Tabel 2 : Koefisien Jalur X1, X2, dan X3 terhadap Y

\begin{tabular}{|c|c|c|c|c|c|c|}
\hline \multicolumn{7}{|c|}{ Coefficients $^{\mathrm{a}}$} \\
\hline & & \multicolumn{2}{|c|}{ Unstandardized Coefficients } & \multirow{2}{*}{$\begin{array}{c}\text { Standardized } \\
\text { Coefficients } \\
\text { Beta }\end{array}$} & \multirow[b]{2}{*}{$\mathrm{t}$} & \multirow[b]{2}{*}{ Sig. } \\
\hline \multicolumn{2}{|c|}{ Model } & B & Std. Error & & & \\
\hline \multirow[t]{4}{*}{1} & (Constant) & 1.917 & 1.957 & & .979 & .336 \\
\hline & Kepemimpinan & 259 & 280 & 127 & .922 & .365 \\
\hline & Lingkungan & .837 & .272 & .430 & 3.072 & .005 \\
\hline & Kompensasi & .808 & 342 & .424 & 2.365 & .026 \\
\hline
\end{tabular}

Berdasarkan tabel 1.2 dapat diketahui bahwa nilai signifikansi gaya kepemimpinan (X1) terhadap motivasi berada diatas nilai standar yang telah ditentukan yaitu sebesar 0.05, maka gaya kepemimpinan tidak memiliki pengaruh yang signifikan terhadap motivasi. Maka dari itu peneliti selanjutnya akan menghitung koefisien jalur substruktur 1 dengan menggunakan metode trimming yaitu dengan mengeliminasi variable eksogen yang tidak memiliki pengaruh yang signifikan.

\section{Metode Trimming}

Pada penelitian ini variable gaya kepemimpinan tidak diikutsertakan pada penghitungan koefisien jalur. 
Tabel 3 : Koefisien Jalur X2 dan X3 Terhadap Y

\begin{tabular}{|c|c|c|c|c|c|c|}
\hline \multicolumn{7}{|c|}{ Coefficients $^{\mathrm{a}}$} \\
\hline & & \multicolumn{2}{|c|}{ Unstandardized Coefficients } & \multirow{2}{*}{$\begin{array}{c}\text { Standardized } \\
\text { Coefficients } \\
\text { Beta } \\
\end{array}$} & \multirow[b]{2}{*}{$\mathrm{t}$} & \multirow[b]{2}{*}{ Sig. } \\
\hline \multicolumn{2}{|c|}{ Model } & $\mathrm{B}$ & Std. Error & & & \\
\hline \multirow[t]{3}{*}{1} & (Constant) & 3.010 & 1.553 & & 1.939 & .063 \\
\hline & Lingkungan & .847 & .272 & .435 & 3.120 & .004 \\
\hline & Kompensasi & 1.005 & .265 & .528 & 3.787 & .001 \\
\hline
\end{tabular}

Sumber : Data yang diolah SPSS

Selanjutnya untuk mengetahui besar pengaruh koefisien determinasi dengan hasil sebagai variabel eksogen terhadap variabel endogen berikut : pada substruktur 1 maka dilakukan pengujian

Tabel 4 : Koefisien Determinasi X2 dan X3 Terhadap Y

\begin{tabular}{|l|c|r|r|c|}
\hline \multicolumn{5}{|c|}{ Model Summary } \\
\hline Model & $\mathrm{R}$ & R Square & $\begin{array}{c}\text { Adjusted R } \\
\text { Square }\end{array}$ & $\begin{array}{c}\text { Std. Error of the } \\
\text { Estimate }\end{array}$ \\
\hline 1 & $.929^{\mathrm{a}}$ & .864 & .854 & 2.429230 \\
\hline \multicolumn{5}{|c|}{ Sumber : Data yang diolah SPSS } \\
\hline
\end{tabular}

Berdasarkan tabel 1.3 dan 1.4 maka peneliti dapat membuat bagan substruktur 1 sebagai berikut :

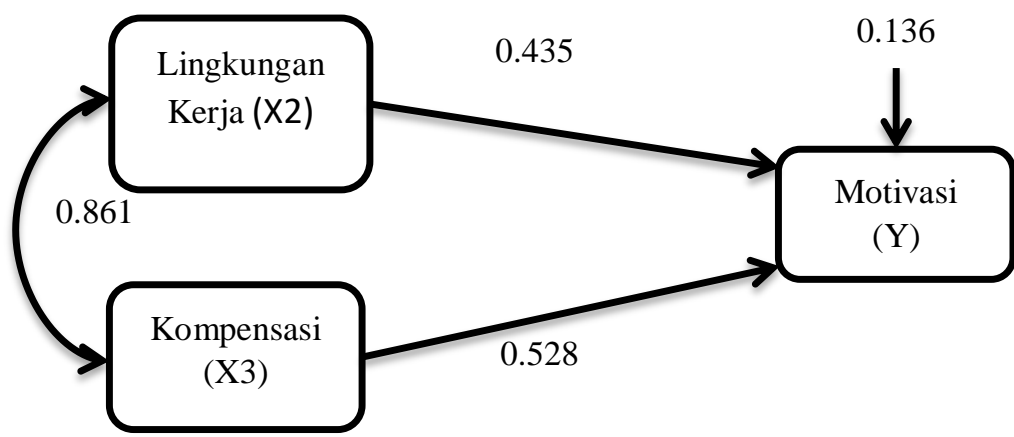

Gambar 2 : Jalur Substruktur 1

Berdasarkan gambar diatas maka persamaan struktur dari substruktur 1 adalah :

$\mathrm{y}=0.435 x_{1}+0.528 x_{2}+0.136(1)$

\section{Uji Hipotesis Substruktur 1}

Berdasarkan tabel 1.3 dapat dilihat bahwa nilai signifikansi masing masing variabel eksogen yaitu Lingkungan kerja dan kompensasi adalah 0.004 dan 0.001 dimana nilai tersebut berada dibawah nilai signifikansi yang telah ditetapkan sebesar 0.05. Maka secara parsial lingkungan kerja dan kompensasi memiliki pengaruh yang signifikan terhadap motivasi. 
Tabel 5 : Tabel ANNOVA Substruktur 1

\begin{tabular}{|c|c|c|c|c|c|c|}
\hline \multirow[b]{2}{*}{ Model } & \multicolumn{6}{|c|}{ ANOVA $^{\mathrm{a}}$} \\
\hline & & Sum of Squares & $\mathrm{df}$ & Mean Square & $\mathrm{F}$ & Sig. \\
\hline \multirow[t]{3}{*}{1} & Regression & 1016.375 & 3 & 338.792 & 57.092 & $.000^{\mathrm{b}}$ \\
\hline & Residual & 154.288 & 26 & 5.934 & & \\
\hline & Total & 1170.663 & 29 & & & \\
\hline
\end{tabular}

Pada tabel 1.5 dapat dilihat bahwa nilai signifikansi menunjukan 0.00 dimana hasil tersebut berada dibawah maksimal standar eror yang telah ditetapkan yaitu sebesar 5\% atau $0.00<0.05$ maka dapat dikatakan bahwa gaya kepemimpinan, lingkungan kerja dan kompensasi secara simultan berpengaruh secara signifikan terhadap motivasi.

\section{Substruktur 2}

Substruktur 2 mencakup pengaruh antara variabel motivasi terhadap kinerja pegawai dimana nilai koefisien jalur disajikan pada tabel berikut :

\section{Tabel 6 : Koefisien Substruktur 2}

\begin{tabular}{|c|c|c|c|c|c|c|}
\hline & & & Coefficients $^{\mathrm{a}}$ & & & \\
\hline & & & & Standardized & & \\
\hline & & Unstandardize & Coefficients & Coefficients & & \\
\hline Model & & B & Std. Error & Beta & $\mathrm{t}$ & Sig. \\
\hline 1 & (Constant) & 1.570 & 1.481 & & 1.060 & .298 \\
\hline & Motivasi & .816 & .065 & .921 & 12.499 & .000 \\
\hline
\end{tabular}

a. Dependent Variable: Kinerja

Sumber : Data yang diolah SPSS

Selanjutnya untuk mengetahui besar pengaruh variabel motivasi terhadap kinerja, maka dilakukan uji koefisien determinasi dengan hasil sebagai berikut :

Tabel 7 : Koefisien Determinasi Substruktur 2

\begin{tabular}{|c|c|c|c|c|}
\hline \multicolumn{5}{|c|}{ Model Summary } \\
\hline Model & $\mathrm{R}$ & R Square & $\begin{array}{c}\text { Adjusted R } \\
\text { Square } \\
\end{array}$ & $\begin{array}{c}\text { Std. Error of the } \\
\text { Estimate }\end{array}$ \\
\hline 1 & $.921^{\mathrm{a}}$ & .848 & .843 & 2.234298 \\
\hline
\end{tabular}

a. Predictors: (Constant), Motivasi

Sumber : Data yang diolah SPSS

Berdasarkan tabel 1.5 dan 1.6 maka peneliti

dapat membuat bagan substruktur 2 sebagai

berikut : 


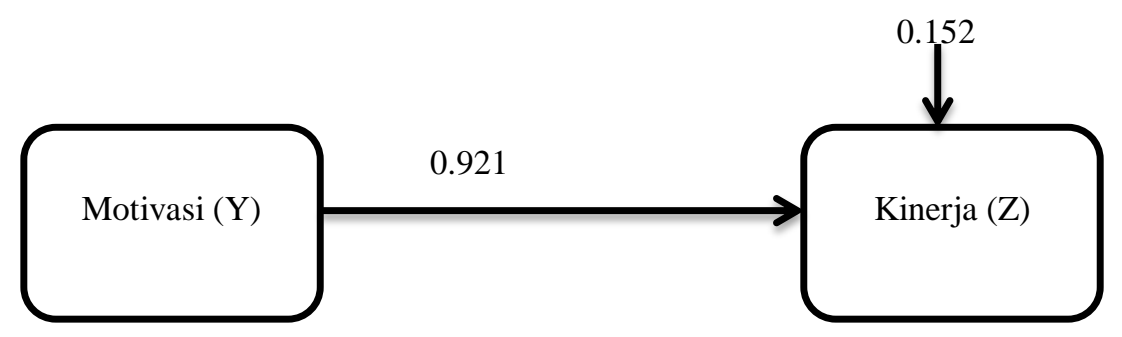

Gambar 3 : Jalur Substruktur 2

Berdasarkan gambar di atas maka persamaan struktur dari substruktur 2 adalah :

$\mathrm{Z}=0.921 Y+0.152(2)$

\section{Uji Hipotesis Substruktur 2}

Berdasarkan tabel 1.6 dapat dilihat bahwa nilai signifikansi variabel motivasi terhadap kinerja adalah sebesar 0.00 dimana hasil tersebut berada dibawah nilai standar yang telah ditetapkan yaitu sebesar 0.05. Maka pengaruh motivasi terhadap kinerja pegawai dinyatakan signifikan.

\section{Substruktur 3}

Pada substruktur 3 mencakup pengaruh variabel kepemimpinan, lingkungan kerja, dan kompensasi terhadap kinerja melalui motivasi. Dimana hasil nilai koefisien disajikan pada tabel berikut :

Tabel 8 : Koefisien Substruktur 3 Coefficients $^{\mathrm{a}}$

\begin{tabular}{|c|c|c|c|c|c|c|}
\hline & & & & \multirow{3}{*}{$\begin{array}{c}\text { Standardized } \\
\text { Coefficients } \\
\text { Beta } \\
\end{array}$} & \multirow[b]{3}{*}{$\mathrm{t}$} & \multirow[b]{3}{*}{ Sig. } \\
\hline \multirow[b]{2}{*}{ Model } & & \multicolumn{2}{|c|}{ Unstandardized Coefficients } & & & \\
\hline & & $\mathrm{B}$ & Std. Error & & & \\
\hline \multirow[t]{3}{*}{1} & (Constant) & 3.116 & 1.646 & & 1.893 & .069 \\
\hline & Lingkungan & .846 & .288 & .490 & 2.940 & .007 \\
\hline & Kompensasi & .742 & .281 & .440 & 2.636 & .014 \\
\hline
\end{tabular}

a. Dependent Variable: Kinerja

Sumber : Data yang diolah SPSS

Selanjutnya untuk mengetahui besar

kinerja, maka dilakukan uji koefisien pengaruh variabel kepemimpinan, determinasi dengan hasil sebagai berikut :

lingkungan kerja, dan kompensasi terhadap

Tabel 9 : Koefisien Determinasi Substruktur 3

\begin{tabular}{cc|c|c|c} 
& & \multicolumn{2}{c}{ Model Summary } \\
Model & $\mathrm{R}$ & R Square & $\begin{array}{c}\text { Adjusted R } \\
\text { Square }\end{array}$ & $\begin{array}{c}\text { Std. Error of the } \\
\text { Estimate }\end{array}$ \\
\hline 1 & $.897^{\mathrm{a}}$ & .805 & .791 & 2.575769 \\
\hline
\end{tabular}

a. Predictors: (Constant), Kompensasi, Lingkungan Sumber : Data yang diolah SPSS 
Berdasarkan tabel 1.7 dan 1.8 maka peneliti dapat membuat bagan substruktur 3 sebagai berikut :

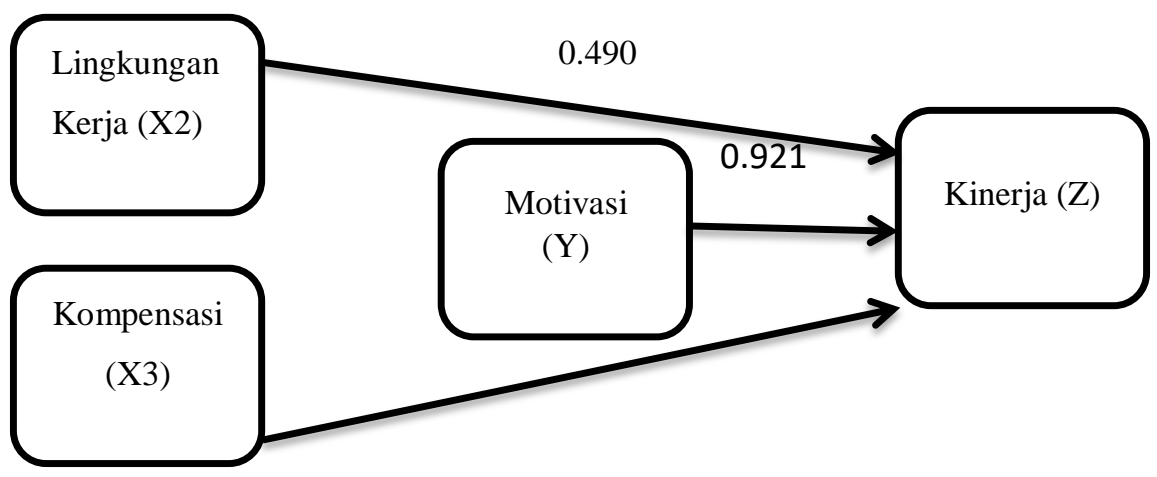

Gambar 4 : Jalur Substruktur 3

Berdasarkan gambar diatas maka persamaan struktur dari substruktur 3 adalah :

$\mathrm{Z}=0.490 \mathrm{x}_{1}+0.440 \mathrm{x}_{2}+0.921 \mathrm{y}$

\section{Uji Hipotesis Substruktur 3}

Berdasarkan tabel 1.7 dapat dilihat bahwa nilai signifikansi variabel lingkungan kerja dan kompensasi terhadap kinerja adalah sebesar 0.07 dan 0.014 dimana hasil tersebut berada dibawah nilai standar yang telah ditetapkan yaitu sebesar 0.05. Maka pengaruh lingkungan kerja dan kompensasi terhadap kinerja pegawai secara parsial dinyatakan signifikan.

\section{Tabel 10 : ANNOVA Substruktur 3}

\begin{tabular}{|c|c|c|c|c|c|c|}
\hline \multicolumn{7}{|c|}{ ANOVA $^{a}$} \\
\hline Model & & Sum of Squares & $\mathrm{df}$ & Mean Square & $\mathrm{F}$ & Sig. \\
\hline \multirow[t]{3}{*}{1} & Regression & 745.143 & 3 & 248.381 & 37.007 & $.000^{\mathrm{b}}$ \\
\hline & Residual & 174.507 & 26 & 6.712 & & \\
\hline & Total & 919.649 & 29 & & & \\
\hline
\end{tabular}

Sumber : Data yang diolah SPSS

Pada tabel 1.9 dapat dilihat bahwa nilai signifikansi menunjukan 0.00 dimana hasil tersebut berada dibawah maksimal standar eror yang telah ditetapkan yaitu sebesar 5\% atau $0.00<0.05$ maka dapat dikatakan bahwa gaya kepemimpinan, lingkungan kerja dan kompensasi secara simultan berpengaruh secara signifikan terhadap kinerja karyawan.

\section{KESIMPULAN}

Hasil analisis data yang dilakukan pada penelitian ini menunjukan bahwa kepemimpinan tidak memiliki pengaruh yang signifikan terhadap motivasi dan kinerja, namun lingkungan kerja dan kompensasi memberikan pengaruh yang signifikan terhadap motivasi dan kinerja baik secara parsial maupun simultan. 


\section{DAFTAR PUSTAKA}

[1] S. Robbins, Perilaku Organisasi. Jakarta: , Penerbit Salemba Empat, 2015.

[2] H. Uno, Teori Motivasi dan Pengukurannya. Jakarta: PT Bumi Aksara, 2011.

[3] E. S. A. \& I. R. Prakoso, Rayka Dantyo, "Pengaruh Lingkungan Kerja Terhadap Motivasi Kerja Dan Kinerja Karyawan," J. Adm. Bisnis, vol. |Vol. 14 N, 2014.

[4] Sedarmayanti, Manajemen Sumber Daya Manusia. Bandung: Refika Aditama, 2017.

[5] N. L. K. S. Maryani, A. A. D. Widyani, and N. P. A. S. Saraswati, "Pengaruh Kompensasi Finansial Terhadap Kinerja Karyawan Dengan Motivasi Sebagai Variabel Intervening Pada Pt Arta Sedana Retailindo Cabang Hardys Malls Sanur Pengaruh Kompensasi Finansial Terhadap Kinerja Karyawan Dengan Motivasi Sebagai Variabel Inter," VALUES, vol. 1, no. 2, pp. 53-67, Apr. 2020, Accessed: Sep. 21,

2021. [Online]. Available: http://ejournal.unmas.ac.id/index.php/value/a rticle/view/813.
[6] M. F. R. Elzi Syaiyid, Hamidah Nayati Utami, "Pengaruh Gaya Kepemimpinan Terhadap Motivasi Kerja," J. Adm. Bisnis, vol. Vol. 1 No., 2013.

[7] L. H. Widyatmini, "Hubungan Kepemimpinan, Kompensasi, dan Kompetensi Terhadap Kinerja Pegawai Dinas Kesehatan Kota Depok," J. Ekon. Bisnis, vol. No.2 Vol.1, 2008.

[8] H. K. Tomy Sun Siagian, "Pengaruh Gaya Kepemimpinan Dan Lingkungan Kerja Terhadap Kinerja Karyawan Dengan Kepuasan Kerja Sebagai Variabel Intervening," Maneggio J. Ilm. Magister Manaj., vol. Vol 1, No., 2014.

[9] A. P. Mangkunegara, Sumber Daya Manusia Perusahaan, Cetakan ke. Bandung: Remaja Rosdakarya, 2015.

[10] S. Jannah, E. F., Tobing, D. S. K., \& Sunardi, "Pengaruh Lingkungan Kerja dan Kompensasi Terhadap Kinerja Melalui Motivasi Karyawan Bagian Produksi UD," e-Journal Ekon. Bisnis dan Akunt., 2017. 